\title{
Financial Support for Smart Manufacturing towards Industry 4.0 in the Context of Sustainable Development ${ }^{*}$
}

\author{
Natalita O. Bulavinova ${ }^{i}$, Anastasita S. Ihnatchenko ${ }^{i i}$
}

The transformational changes in the ecosystem over the past two decades have led to the technological leap that made all scientists talk about the Fourth Industrial Revolution. Against the background of the changes that the revolution personifies, the determining factor is the study of the issue of smart manufacturing as the main link in the revolution. The paradigm in the development of smart manufacturing is not only the development of such technologies as artificial intelligence, blockchain in manufacturing, the Industrial Internet of Things, robotics, cybersecurity, etc. but also the financial security of all its processes. Since smart manufacturing is a specific category of economic development, it also requires specific funding. The article investigates the terminological definition of Smart Manufacturing. The Smart Manufacturing market was studied, and a forecast for the coming years was made. At the beginning of 2019, the market was USD 204,95 billion and USD 422.88 billion by 2025 . The work is substantiated, Smart Factory is a mechanism workshop for Smart Manufacturing. Although, in our opinion, Smart Factory is the environment for the formation of technologies, that improve the work of manufacturing mechanisms. The importance of becoming Industry 4.0 based on the principles of sustainable development is determined. Since human activity has led to the destruction of the ecosystem. The budgets of the world's leading countries for the development of Smart Manufacturing have been studied. The leader is Germany. It is planned to spend USD 200 million of public funding and USD 300 million of private one (business investment). The authors noted the importance of implementing responsible investing. The investment climate of Ukraine has been studied. In 2019, Ukraine is ranked 64th in the Doing Business ranking, 85th in the Global Competitiveness Index, 47th in the Global Innovation Index and 126th in the Transparency International ranking. The lack of implementation of almost all principles of Smart Manufacturing is noted.

Keywords: smart manufacturing, sustainable development, responsible investment, Industry 4.0.

УДК 336.7:[338.36:502.131.1]

JEL Codes: O13, O15, O16, $\mathrm{O} 18$

Introduction. Today, determining the level and mechanisms of financial support for the formation of smart manufacturing is a priority and is held under the sustainable development auspices, since humanity cannot cope with the regenerating changes in the ecosystem and try to find ways out of the crisis. Therefore, responsible investment fits the best for achieving goals, as it takes into account environmental, economic, governance factors.

Problem statement. The understanding of financing tools, in particular investment in the context of smart manufacturing, is quite ramified and not fully defined in achieving sustainable

\footnotetext{
${ }^{i}$ Nataliia O. Bulavinova, Postgraduate Student, Department of Accounting and Taxation, Oleg Balatskyi Academic and Research Institute of Finance, Economics and Management, Sumy State University;

${ }^{i i}$ Anastasiia S. Ihnatchenko, Postgraduate Student of the Department of Economics, Entrepreneurship and Business Administration, Sumy State University.

* Матеріал підготовлено в рамках НДР «Фрактальна модель трансформації фондового ринку України: соціально-відповідальне інвестування для досягнення Цілей сталого розвитку» № державної реєстрації $0121 \mathrm{U} 100473$.
}

(C) N. O. Bulavinova, A. S. Ihnatchenko, 2020.

https://doi.org/10.21272/mer.2020.90.06

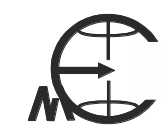


Н. О. Булавінова, А. С. Ігнатченко.

Фінансове забезпечення розумного виробництва на шляху до Industry 4.0 в контексті сталого розвитку

development. Among domestic scientists, the subject was dealt with in particula V. P. Vyshnevskyi and S. I. Kniaziev, who consider smart manufacturing from a cyberphysical point of view, which gives an incomplete understanding of the essence of the definition [1]. V. I. Skitsko mainly considers the issue of smart manufacturing in the structural and classification context and offers a scheme for the interaction of the state, science, and business to achieve the Fourth Industrial Revolution [2]. O. S. Honcharenko, O. O. Barabash and M. U. Tszianmin consider the smart manufacturing concept in the context of sustainable development and add some systemic principles [3]. Among foreign scientists, it is necessary to admit Chunguang Bai and Patrick Dallasega, who developed a method for assessing technologies of the Fourth Industrial Revolution to ensure sustainable development. This allows the transition to the Fourth Industrial Revolution but under conditions of assessing each technology to determine their impact on the industry and sustainable development [4].

The issues were also investigated by Kahra J., Saurabh Ahluwalia, Raj V. Mahto, M. Mazzucato etc. Joanna Wyrwa researched the most related topic and noted the importance of investment as the main indicator of increasing the level of digitalization, automation, and robotization, e. i. the tools for smart manufacturing [5]. The study of the issue of smart manufacturing is quite ramified by its empirical and functional definition. Therefore, the task of the research is to consider the data on the formation of smart manufacturing and to determine the institutional mechanisms and the level of its financial support.

The purpose is to consider the problem of the formation of smart manufacturing and the foundations of its financing under the sustainable development auspices.

Results of the research. The dynamics of the technology evolution process pushed the economy and society to the transformation of the strategies of development and doing business. Today, technological progress has led to the automation of every stage and process of manufacturing that is defined as the Fourth Industrial Revolution.

The Fourth Industrial Revolution is a stage of human life, when an individual is surrounded by cyber-physical systems absolutely everywhere, where a computerized network can exist, without the direct participation of the human. In 2010 Germany presented the private and public programme "Industry 4.0". Since then the definition of Industry 4.0 is synonymous with the Fourth Industrial Revolution in most research of scientists.

The mechanisms of Industry 4.0 formation are the development of real and virtual phases of digitalization, automation and robotization. Their tools are the development and implementation of smart technology such as Big Data, Internet of Things (IIoT), Virtual and Other realities, Blockchain, Smart Factory, Smart Cities, Machine learning, etc.

The key definition of Industry 4.0 is the connection of "smart equipment" at "smart manufacturing". The largest component is still "Smart Manufacturing". The definition is interpreted differently in different sources and sometimes is identified with "Smart Factory". Although, in our opinion, Smart Factory is the environment for the formation of technologies, that improve the work of manufacturing mechanisms. That is, Smart Factory is a mechanism workshop for Smart Manufacturing. Some definitions of "Smart Manufacturing" are given in Table 1.

The definition of Andrew Kusiak is the most complete and it fully reveals the Smart Manufacturing paradigm.

Since Industry 4.0 goes hand in hand with the concept of sustainable development, then responsible investment and its forms play an important role in smart manufacturing development. 
Nataliia O. Bulavinova, Anastasiia S. Ihnatchenko.

Financial Support for Smart Manufacturing towards Industry 4.0 in the Context of Sustainable Development

Responsible investment is the choice of an investment strategy taking into account environmental, economic, corporate and governance factors (ESG - environmental, social, governance), as well as the market stability in the long term [10].

Terminological definition of the concept of "Smart Manufacturing"

Table 1

\begin{tabular}{|c|l|l|}
\hline No. & \multicolumn{1}{|c|}{ Source } & \multicolumn{1}{c|}{ Terminology } \\
\hline 1 & Andrew Kusiak & $\begin{array}{l}\text { The form of production, the development of which is the } \\
\text { integration of production assets with digital, communication } \\
\text { technologies, modeling, forecasting, management and design } \\
\text { [6] }\end{array}$ \\
\hline 2 & $\begin{array}{l}\text { National Institute of } \\
\text { Standards and } \\
\text { Technology (NIST) }\end{array}$ & $\begin{array}{l}\text { The production system that is fully integrated with changing } \\
\text { production conditions as well as the demand and supply of a } \\
\text { customer[7] }\end{array}$ \\
\hline 3 & Pankaj Raushan & $\begin{array}{l}\text { The combination of a collection of different technologies and } \\
\text { solutions for the implementation of a production environment } \\
\text { [8] }\end{array}$ \\
\hline 4 & Jim Devista at al & $\begin{array}{l}\text { The implementation of the Internet of Things (IIoT) at all } \\
\text { stages of production and throughout the supply chain [9] }\end{array}$ \\
\hline
\end{tabular}

Source: compiled by authors based on the analysis $[6,7,8,9]$

The investment has also changed and has many forms due to the influence of the globalization processes and time:

- Socially responsible investing (SRI) - investment that includes social and environmental criteria;

- Sustainable investing - choosing a strategy that excludes assets associated with damage to environmental or social sustainability;

- Thematic investing - investment strategies that have a well-defined topic;

- Green investing - investing in companies or technologies that do not cause damage to the environmental situation;

- Impact investing - targeted investment (achieving a social or environmental goal).

It is rather difficult to determine the forms and types of responsible investment since there is no clearly defined paradigm for their classification.

The global market of Smart Manufacturing in early 2019 was USD 204.95 billion. At the end of 2019, it is already USD 252.29 billion and is expected to reach USD 422.88 billion by 2025 , recording a CAGR of $9.33 \%$ over the forecast period (2019-2020). The global Smart Manufacturing market is expected to reach USD 506.33 billion by 2027 , and during the forecast period the CAGR will be $12.2 \%$. The forecast is visualized in Figure 1.

Smart Manufacturing has a decisive influence on the relationship between technologysociety-biological species (human, individual). Today, the priority is not only to reach the top of Industry 4.0 but to achieve it under the sustainable development auspices. Since human activities have led to the destruction of the ecosystem, the task of Smart Manufacturing is to bring Industry 4.0 on a trajectory of sustainable and resilient development without damage to the ecosystem.

For example, Germany plans to include into budget the costs for the development of Industry 4.0, the basis of which is Smart Manufacturing. It is planned to spend USD 200 million of public funding and USD 300 million of private one (business investment). 
Н. О. Булавінова, А. С. Ізнатченко.

Фінансове забезпечення розумного виробництва на шляху до Industry 4.0 в контексті сталого розвитку

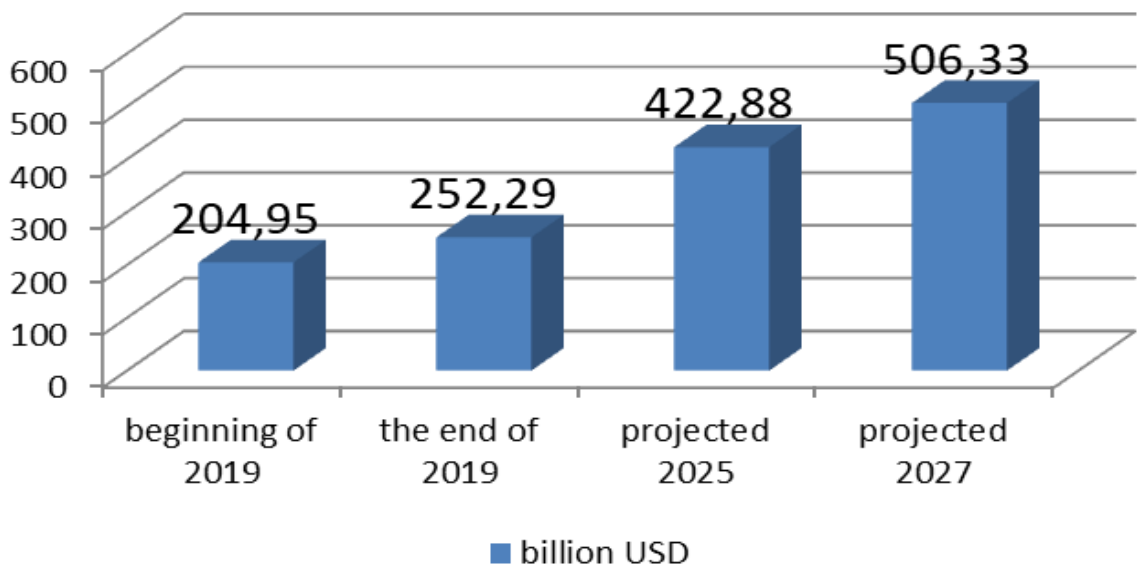

Figure 1. The volume of the world market for Smart manufacturing [11]

The program focuses on technologies for the development of the Internet of Things (IoT) and Cyber-Physical Systems (CPS) [12].

Singapore, according to the Industry Transformation Map (ITM) programme, launched in 2016, invested SGD 3.3 billion in the development and research of production and engineering links in 2020 [13].

In turn, the EU within the framework of the Horizon 2020 programme invested in research and innovation about EUR 1.15 billion from 2014 to 2020 [14].

Joining the innovation revolution, the USA and Great Britain at the beginning of the creation of the concepts of Manufacturing USA and Catapult centers declared 700 and 430 million dollars respectively.

During 2019-2020, Great Britain invested USD 744 million to create a future innovative step in the Catapult centers programme for research and development. The investments were made mainly for Core Grant Investment in capability - USD 236 million; Attracts commercial Investment in Projects - USD 154 million; Collaborative R\&D Wins - USD 130 million, CR\&D Leveraged - USD 224 million [15].

The USA annual report 2020 states that the growth trend of investments in Technology and Workforce Projects was 20\% more during 2019-2020 than in the previous reporting period. Investment in new Projects for 2019-2020 makes USD 9.7 million [16].

Smart Manufacturing development programmers have been developed and implemented in other countries. Therefore, the integration of financial instruments to ensure Smart Manufacturing should be a priority of the state financial policy. The state plays a key role in this matter, as it must create the necessary conditions for businesses to modernize and switch to smart manufacturing technologies.

Talking about financing smart manufacturing it should be noted that each country has its own unique set of financing tools based on the local economic and political situation.

Most often, the instruments that are used for business financing by the state are as follows:

- reduced tax rates;

- tax holidays for newly-formed innovative manufacture;

- state grants for the implementation of innovative projects;

- tax credit. 
Nataliia O. Bulavinova, Anastasiia S. Ihnatchenko.

Financial Support for Smart Manufacturing towards Industry 4.0 in the Context of Sustainable Development

In the context of other infrastructures, investments (public, private, mixed, investments of international organizations) are the determining instrument for the additional attraction of the capital.

Investments, especially foreign ones, provide not only cash inflow but also the emergence of new technological transformations. The level and readiness of the country for investors is determined by the investment attractiveness ranking.

In 2019, Ukraine is ranked $64^{\text {th }}$ in the Doing Business ranking, $85^{\text {th }}$ in the Global Competitiveness Index, $47^{\text {th }}$ in the Global Innovation Index and $126^{\text {th }}$ in the Transparency International ranking. This is a negative screening for the investment climate of the state.

In Ukraine, the formation of Smart Manufacturing is being developed with the support of the Association of Industrial Automation of Ukraine (APPAU) and the Concept of Industrial Movement 4.0. The formation of smart manufacturing is at an empirical (document) stage.

There is no clearly defined amount of financing for Smart Manufacturing in Ukraine. Investment support for innovative, scientific and technological development in the formation of sustainable smart manufacturing remains a priority.

The main inflow of investments to Ukraine is carried out by foreign investors. So, according to the NBU, as of June 30, 2020 foreign direct investment in Ukraine makes USD 50.311 billion. It should be noted the top 5 investor countries. They are as follows: Cyprus (USD 15494 million), the Netherlands (USD 10261 million), Switzerland (USD 3083 million), Great Britain (USD 3054 million) and Germany (USD 2316 million) [17].

Ukraine has the potential to develop Smart Manufacturing but under conditions of reasonable financial policy.

Conclusions and prospects of further research. The development of Smart Manufacturing is an integral part of Industry 4.0 and a task of achieving sustainable development. The main problem is financial and institutional leverages, which are based on:

- state and financial support for the scientific and research sector;

- improving the investment climate.

It should be noted that moderate development of the world Smart Manufacturing market is observed. As for Ukraine, the research results show rather slow (passive) development. Despite the creation of a National Industry 4.0, we observe the scant involvement of the state. The implementation of almost all strategy principles and business support is missing.

It should be noted that the country has a sufficiently developed centre of skilled personnel, namely engineers, to support the development of smart manufacturing. But state is gradually losing them since there are no jobs.

\section{References}

1. Vyshnevskyi, V. P., Kniaziev, S. I. (2017). Smart promyslovist: perspektyvy i problemy [Smart industry: prospects and problems]. Ekonomika Ukrainy - Economy of Ukraine, 7, 22-37 [in Russian].

2. Skitsko, V. I. (2016). Industriia 4.0 yak promyslove vyrobnytstvo maibutnoho [Industry 4.0 as the industrial production of the future]. Investytsii praktyka ta dosvid - Investments: practice and experience, 5, 33-40. [in Ukrainian].

3. Goncharenko, O. S., Barabash, O. O., Jianming, M. U. (2019). Genesis definition concept of "Industry 4.0" in the context of sustainable development. Economics: time realities, 3 (43), 22-30.

4. Bai, Ch., Dallasega, P., Orzesb, G. \& Sarkis, J. (2020). Industry 4.0 technologies assessment: A sustainability perspective. International Journal of Production Economics, 229, 107776. https://doi.org/10.1016/j.ijpe.2020.107776 
Н. О. Булавінова, А. С. Іәнатченко.

Фінансове забезпечення розумного виробництва на шляху до Industry 4.0 в контексті сталого розвитку

5. Wyrwa, J. (2020). A review of the European Union financial instruments supporting the innovative activity of enterprises in the context of Industry 4.0 in the years 2021-2027. Entrepreneurship and Sustainability Issues, 8 (1), 1146-1161. https://doi.org/10.9770/jesi.2020.8.1(77)

6. Kusiak, A. (2018). Smart manufacturing. International Journal of Production Research, 56 (1-2), 508-517, https://doi.org/10.1080/00207543.2017.1351644

7. National Institute of Standards and Technology (NIST). Retrieved from https://www.nist.gov/

8. Pankaj, R. (2018). The Top 7 Things to Know About Smart Manufacturing. MarketResearch.com, Retrieved from https://blog.marketresearch.com/the-top-7-things-to-know-about-smartmanufacturing

9. Davisa, J., Edgarb, T., Porterc, J., Bernadend, J. \& Sarlie, M. (2012). Smart manufacturing, manufacturing intelligence and demand-dynamic performance. Computers \& Chemical Engineering, 47, 145-156, https://doi.org/10.1016/j.compchemeng.2012.06.037

10. Principles for Responsible Investment (PRI). Retrieved from https://www.unpri.org/pri/anintroduction-to-responsible-investment/what-is-responsible-investment

11. Smart manufacturing market size, share and COVID-19 impact analysis (2020). Market research report. Retrieved from https://www.fortunebusinessinsights.com/smart-manufacturing-market103594.

12. Key lessons from national industry 4.0 policy initiatives in Europe (2017). Digital Transformation Monitor. Retrieved from https://ec.europa.eu/growth/toolsdatabases/dem/monitor/sites/default/files/DTM_Policy\%20initiative\%20comparison\%20v1.pdf

13. Research, Innovation and Enterprise (RIE) 2020 plan. (2020). SPETA. Retrieved from https://speta.org/rie-2020/

14. The Factories of the Future. (2020). European Commission. Retrieved from https://ec.europa.eu/digital-single-market/en/factories-future

15. Creating the Future through innovation 2019-20 (2020). Recovery and Resilience. Retrieved fromhttps://s3.euwest1.amazonaws.com/media.www.catapult/wpcontent/uploads/2020/11/27121214/ Catapult-Network-Impact-Brochure-2020-FINAL.pdf

16. Annual report 2019-20 (2020). The National Institute for Innovation in Manufacturing Biopharmaceuticals. Retrieved from https://niimbl.org/Downloads/NIIMBL_Annual_Report_201920_FINAL.pdf?mc_cid=13bd789646\& mc eid=bbfd $3 \mathrm{~d} 2928$

17. Natsionalnyi bank Ukrainy $(N B U)$ - National Bank of Ukraine. Retrieved from https://bank.gov.ua/

Manuscript received 18 October 2020

Финансовое обеспечение разумного производства на пути к Industry 4.0 в контексте устойчивого развития

\author{
НАТАЛИЯ АЛЕКСАНДРОВНА БУЛАВИНОВА*, \\ АНАСТАСИЯ СЕРГЕЕВНА ИГНАТчеНКО ** \\ * аспирантка кафедры бухгалтерского учета и налогообложения \\ Учебно-научного института финансов, экономики и менеджмента \\ имени Олега Балацкого \\ Сумского государственного университета, \\ ул. Р.-Корсакова, 2, г. Сумыл, 40007, Украина \\ тел.: 00-380-669157547, e-mail: n.bulavinova@uabs.sumdu.edu.ua \\ ** аспирантка кафедры экономики, предпринимательства и бизнес-администрирования \\ Сумского государственного университета, \\ ул. Р.-Корсакова, 2, г. Сумы, 40007, Украина \\ тел:00-380-542-332223, e-mail: a.ihnatchenko@econ.sumdu.edu.ua
}


Nataliia O. Bulavinova, Anastasiia S. Ihnatchenko.

Financial Support for Smart Manufacturing towards Industry 4.0 in the Context of Sustainable Development

Трансформационные изменения в экосистеме за последние два десятилетия привели к технологическому прорыву, что заставило весь научный мир заговорить о Четвертой промышленной революции. На фоне изменений, которые олицетворяет революция, определяющим является исследование вопроса разумного производства как главного звена революции. Парадигмой в развитии разумного производства является не только развитие технологий: искусственный интеллект, блокчейн в производстве, промышленный интернет вещей, робототехника, кибербезопасность и проч., но и финансовая обеспеченность всех его процессов. Так как разумное производство является специфической категорией экономического развития, то требует и специфического финансирования. В статье исследуется терминологическое определение Smart Manufacturing. Был изучен рынок Smart Manufacturing и сделан прогноз на ближайшие годы. Отмечается, что на начало 2019 рынок составлял 204,95 млрд долларов США, а на 2025 прогнозируется 422,88 млрд долларов США. В работе обосновано, что Smart Factory является механизменным цехом для Smart Manufacturing, поскольку Smart Factory, по мнению авторов, является средой становления технологий, при которых улучшается работа механизмов производства. Определена важность становления Industry 4.0 по принципам устойчивого развития, так как деятельность человечества привела к деструкции экосистемы. Исследовано бюджеты ведущих стран мира для развития Smart Manufacturing. Лидером является Германия, которая планирует заложить в бюджет на развитие программы Industry 4.0, основой которой является Smart Manufacturing 200 млн долл. США государственного финансирования и 300 млн долл. США частного (инвестиции бизнеса). Авторами отмечена важность внедрения ответственного инвестирования. Изучено инвестиционный климат Украины. Так, Украина в 2019 году по рейтингу Doing Business находилась на 64 месте, по рейтингу Global Competitiveness Index - на 85 месте, по рейтингу Global Innovation Index - на 47 месте и по рейтингу Transparency International - на 126 месте.

Ключевые слова: умное производство, устойчивое развитие, ответственное инвестирование, четвертая промышленная революция.

$$
\begin{gathered}
\text { Mechanism of Economic Regulation, 2020, No 4, } 81 \text { - } 89 \\
\text { ISSN 1726-8699 (print) }
\end{gathered}
$$

Фінансове забезпечення розумного виробництва на шляху до Industry 4.0 в контексті сталого розвитку

\author{
НАТАЛІЯ ОЛЕКСАНДРІВНА БУЛАВІНОВА*, \\ АНАСТАСІЯ СЕРГЇ̈ВНА ІГНАТЧЕНКО \\ * аспірантка кафедри бухгалтерського обліку та оподаткування \\ Навчально-наукового інституту фінансів, економіки і менеджменту \\ імені Олега Балачького \\ Сумського державного університету, \\ вул. Р.-Корсакова, 2, м. Суми, 40007, Україна, \\ тел.: 00-380-669157547, e-mail: n.bulavinova@uabs.sumdu.edu.ua \\ ** аспірантка кафедри економіки, підприсмництва та бізнес адміністрування \\ Сумського державного університету \\ вул. Р.-Корсакова, 2, г. Суми, 40007, Україна, \\ тел:00-380-542-332223, e-mail: a.ihnatchenko@econ.sumdu.edu.ua
}

Трансформаційні зміни в екосистемі за останні два десятиліття призвели до технологічного прориву, що змусило весь науковий світ заговорити про Четверту промислову революцію. На тлі змін, які уособлює революція, визначальним є дослідження питання розумного виробництва як головної ланки революції. Парадигмою в розвитку розумного виробництва $\epsilon$ не лише розвиток технологій: штучний інтелект, блокчейн у виробництві, промисловий Інтернет речей, 
Н. О. Булавінова, А. С. Іенатченко.

Фінансове забезпечення розумного виробництва на шляху до Industry 4.0 в контексті сталого розвитку

робототехніка, кібербезпека та інші, а й фінансова забезпеченість всіх його процесів. Так як розумне виробництво $\epsilon$ специфічною категорією економічного розвитку, то потребує i специфічного фінансування. В статті досліджується термінологічне визначення Smart Manufacturing. Був вивчений ринок Smart Manufacturing та здійснено прогноз на найближчі роки. Зазначається, що на початок 2019 року ринок складав 204,95 млрд доларів США, а на 2025 прогнозується 422,88 млрд доларів США. В роботі обгрунтовано, що Smart Factory $\epsilon$ механізаційним цехом для Smart Manufacturing, так як Smart Factory, на думку авторів, $\epsilon$ середовищем становлення технологій, завдяки яким покращується робота механізмів виробництва. Визначено важливість становлення Industry 4.0 за принципами сталого розвитку, так як діяльність людства призвела до деструкції екосистеми. Досліджено бюджети провідних країн світу для розвитку Smart Manufacturing. Лідером $є$ Німеччина, яка планує закласти в бюджет на розвиток програми Industry 4.0, основою якої є Smart Manufacturing 200 млн дол. США державного фінансування та 300 млн дол США приватного(інвестиції бізнесу). Авторами зазначено важливість впровадження відповідального інвестування. Вивчено інвестиційний клімат України. Так, Україна в 2019 році за рейтингом Doing Business знаходиться на 64 місці, за рейтингом Global Competitiveness Index - на 85 місці, за рейтингом Global Innovation Index - на 47 місці та за рейтингом Transparency International - на 126 місці.

Ключові слова: розумне виробництво, сталий розвиток, відповідальне інвестування, четверта промислова революція.

JEL Codes: O13; O15; O16; 018

Table: 1; Figure: 1; References: 17

Language of the article: English

Лimepamypa

1. Вишневський, В. П. Смарт промисловість: перспективи і проблеми / В. П. Вишневський, С. І. Князєв // Економіка України. - 2017. - № 7. - С. 22-37.

2. Скіцьько, B. I. Індустрія 4.0 як промислове виробництво майбутнього / В. І. Скіцько // Інвестиції: практика та досвід. - 2016. - № 5. - С. 33-40.

3. Goncharenko, O.S. Genesis definition concept of "Industry 4.0" in the context of sustainable development / O. S. Goncharenko, O. O. Barabash, M. U. Jianming // Economics: time realities. 2019 - №3 (43) - C. 22-30.

4. Bai, Ch. Industry 4.0 technologies assessment: A sustainability perspective. / Ch. Bai, P. Dallasega, G. Orzesb \& J. Sarkis // International Journal of Production Economics. - 2020. - № 229. https://doi.org/10.1016/j.ijpe.2020.107776

5. Wyrwa, J. A review of the European Union financial instruments supporting the innovative activity of enterprises in the context of Industry 4.0 in the years 2021-2027 / J. Wyrwa // Entrepreneurship and Sustainability Issues. $-2020 . \quad-\quad$ № 8(1). - C. 1146-1161. https://doi.org/10.9770/jesi.2020.8.1(77)

6. Kusiak, A. Smart manufacturing. / A. Kusiak // International Journal of Production Research. - 2018. - № 56 (1-2). - C. 508-517. https://doi.org/10.1080/00207543.2017.1351644

7. National Institute of Standards and Technology (NIST) [Електронний ресурс]. - Режим доступу : https://www.nist.gov/

8. Pankaj, $R$. The Top 7 Thingsto Know About Smart Manufacturing. Market Research.com [Електронний ресурс]. - 2018. - Режим доступу : https://blog.marketresearch.com/the-top-7things-to-know-about-smart-manufacturing

9. Davisa, J. Smart manufacturing, manufacturing intelligence and demand-dynamic performance / J. Davisa, T. Edgarb, J. Porterc, J. Bernadend \& M. Sarlie // Computers \& Chemical Engineering. 2012. - № 47. - C. 145-156. https://doi.org/10.1016/j.compchemeng.2012.06.037

10. Principles for Responsible Investment (PRI) [Електронний ресурс]. - Режим доступу : https://www.unpri.org/pri/an-introduction-to-responsible-investment/what-is-responsible-investment 
Nataliia O. Bulavinova, Anastasiia S. Ihnatchenko. Financial Support for Smart Manufacturing towards Industry 4.0 in the Context of Sustainable Development

11. Smart manufacturing market size, share and COVID-19 impact analysis. [Електронний ресурс] // Market research report. - $2020 . \quad-2$ Режим доступу: https://www.fortunebusinessinsights.com/smart-manufacturing-market-103594

12. Key lessons from national industry 4.0 policy initiatives in Europe [Електронний ресурс] // Digital Transformation Monitor. - 2017. - Режим доступу: https://ec.europa.eu/growth/toolsdatabases/dem/monitor/sites/default/files/DTM_Policy\%20initiative\%20comparison\%20v1.pdf

13. Research, Innovation and Enterprise (RIE) 2020 plan [Електронний ресурс] // SPETA - 2020. Режим доступу : https://speta.org/rie-2020

14. The Factories of the Future [Електронний pecypc] // European Commission. - 2020. - Режим доступу : https://ec.europa.eu/digital-single-market/en/factories-future

15. Creating the Future through innovation 2019-20 [Електронний ресурс] // Recovery and Resilience. - 2020.2 Режим доступу : https://s3.euwest1.amazonaws.com/media.www.catapult/wpcontent/uploads/2020/11/27121214/Cata pult-Network-Impact-Brochure-2020-FINAL.pdf

16. Annual report 2019-20. [Електронний ресурс] // The National Institute for Innovation in Manufacturing Biopharmaceuticals. - 2020 - $\quad$ Режим доступу: https://niimbl.org/Downloads/NIIMBL_Annual_Report_201920_FINAL.pdf?mc_cid=13bd789646\& mc_eid=bbfd3d 2928

17. Національний банк україни (НБУ) [Електронний ресурс]. - Режим доступу: http://www.minjust.gov.ua/0/1963 